\title{
Sex in Development: Science, Sexuality, and Morality in Global Perspective
}

\author{
Edited by Vincanne Adams and Stacy Leigh Pegg. Durham, North Carolina, \\ Duke University Press, 2005, 342 pp., \$24.95 (paperback); 89.95 (hardcover)
}

\author{
Anna C. M. Tijsseling
}

Published online: 28 July 2011

(C) The Author(s) 2011. This article is published with open access at Springerlink.com

By focussing upon (local) sexual practices, this volume analyzes the ways in which science, medicine, technology, and planning rationalities shape (new) conceptions of sexuality. It scrutinizes the ways in which sexuality is construed through projects that "blur cultural, normative and moral boundaries" (p. 7). The volume consists of two elaborate introductory chapters. Theoretically, the editors clarify how Western theories about sex and gender are inadequate in understanding nonWestern sexualities and divide the volume into three parts. The first part of this volume is concerned with the production of sexual subjectivities in Russia, Greece, and Uganda. The second one scrutinizes the normativities of three Asian biopolitical projects. Finally, an African and Indian case deal with resistance to sexual liberal humanism. Although these themes are introduced separately by the editors, this division feels somewhat uneasy given that all chapters deal with at least sexual subjectivity and normativities. Furthermore, most chapters deal with resistance towards "new" or "imposed" sex-related practices.

The chapter by Rivkin-Fish describes what happens when representatives of a North American pharmaceutical company and Russian obstetricians, midwives, and nurses meet. The North Americans try to train the Russians in "professional neutrality" whereas sexual practices are concerned. They want to empower women and disempower professionals where nonprocreative sex is concerned. Her contribution to this volume is somewhat problematic for two reasons. Firstly, within the academic field, sexology and sexual sciences have been frail expertises, which could explain the reluctance of these professionals in (admitting to) leaving choices up to their clients-

A. C. M. Tijsseling ( $₫)$

International Institute of Social History, Cruquiusqweg 31,

1019 AT Amsterdam, The Netherlands

e-mail: ati@iisg.nl even if they would in their practice. And secondly, at least two historians have tried to nuance twentieth century associations with Russia as a sexless society (Carleton, 2005; Healy, 2001). In this contribution, the author reiterates the sexless imagery.

Just like other authors in this volume, Paxson criticizes the adagio of early twentieth century sexologists "per scientiam ad verecundiam" (science brings truth) that resonates in the assumptions of health care workers and sex educators. The Family Planning Association of Greece (FPAG), which tried to persuade Greek women to use contraceptives instead of resorting to abortion is a convincing case in point. "Truth" and making rational choices do not always matter where sexuality is concerned. Although this Association made contraceptives far more accessible than they had been, Greek abortion rates kept on exceeding live birth rates. Paxson's main point is that whereas contraceptives were experienced as liberating for women in other countries, in Greece the contraceptives and their corresponding ethics of "well-being" only complicated the lives of Greek women.

Parikh shows how Ugandan anti-AIDS campaigns are read "queerly" by Ugandan youth. Parikh analyzes the change in information channels for the Ugandan youth due to medicalization processes of sexuality by health care workers, the commercialization of sexual pleasure. Parikh shows how these processes affect the conceptions of their sexual selves. Just as Butt in the Indonesian case (see below) and Paxson in the Greek case, Parikh shows how (inter)national sex education "involves more than 'facts' replacing misconceptions" (p. 58) about sexuality. Still, Parikh's normative conclusion that sex education in the future should not estrange parents from their children comes across as rather odd for the scientific endeavour this volume attempts to be.

In her contribution, Butt analyzes the "runaway wife problem" in Highlands Papua as the effect of changes in reproduction and sexuality practices. Just like in the Tibetan case 
(see below), a foreign state imposes values and norms upon a group of people, in this case of the Dani's. Convincingly, Butt shows how (racist) commonsense opinions pervade Indonesian family planning policies. Butt analyzes how Indonesian outreach workers of regional family planning offices mould sexual subjectivities with their policy practices. She also shows how sex is used to forge (racist) classifications between groups of people.

Dell explores how VCR-technology — with the VCR being symbolic for middle class prosperity - and the flooding of the Indian market with Western pornographic "blue" movies challenges the colonial Indian binary between respectable wives and prostitutes. Dell shows how this colonial imagery worked in the postcolonial Indian sex industry. She concludes that the opening of the Indian market and the influx of Western pornography threatened fixed gendered identities. At the bottom of the hierarchy of the postcolonial sex industry are those who are willing to perform non-Indian sex acts. These women are seen as untouchables by colleagues who do it Indian style. Although Dell explores an interesting terrain, she fails to properly contextualize the Indian commercial sex market. Without information about the proportion of Indian and non-Indian women working in the sex industry, it is hard to fully understand the dynamics between the "virtuous" Indian prostitutes and the Indian prostitutes participating in foreign sex acts. Further, while probing the relationship among power, colonization, and sexual identity formation to explain postcolonial responses towards Western pornography, Dell overlooks one of the most fascinating processes in her endeavour. The British colonial empire created a moral hierarchy between British and Indian women. Why, in turn, did the Indian people make a division among its own women, between wives and prostitutes, if the national identity was saturated with a sexual one and foreign sex was seen as immoral?

The Tibetan chapter is a case in point where cultural clashes are concerned. The Tibetan "sexual revolution" of the 1960 s was juxtaposed to those in Western societies. Instead of a bottom-up process, the Chinese imposed sexual practices and sexual moral top-down with the Cultural Revolution in Tibet. As celibacy changed from one of the highest ideals into a counterrevolutionary act, this new "morality" even involved the raping of resistant Tibetan nuns. As Adams elaborately shows, Tibetan sex became dissociated from religion and primarily conflated with reproduction and fertility rates.

Nguyen explores how confessional technologies brought in by NGO's combating HIV and AIDS changed Francophone West African homosocial spheres. Whereas beforehand homosexual acts and the playing with gendered norms were (partly economic) practices, the confessional technologies of workshops on sexual transmittable diseases changed these practices into forms of gayness. Nguyen concludes that discursive practices, such as narratives of "coming out," cannot be isolated from individual experiences of sexual selves. Remarkably, this conclusion underwrites the claim of Western sexologists throughout the first part of the twentieth century that as long as one discursively practices long enough one can eventually lead a "normal" heterosexual life.

The contribution by Cohen on the Indian concept "kothi," a feminized identity in the community of men who have sex with men (MSM), tries to show how "AIDS cosmopolitanism" influences the meanings of sexual or gendered classifications. He shows that the Western gay/straight binary is inadequate for understanding the Indian classifications concerning the relation between sexual practices and concepts of self. He shows how the term "kothi" became an important denomination within this realm from the 1990s onwards, whereas this concept had been virtually non-existent during his pre-1990s years of research in Indian regions. What is remarkable about this otherwise meticulous approach of Indian semantics is that the concept "woman" apparently is a black box understood as "repeatedly enact [ing] a desire to be penetrated by a real man" (p. 271).

This volume is an interesting read for social scientists, social historians, and health care workers. By bringing such richly documented case studies together, it inspires researchers who study sexuality to reflect upon how exactly sexuality is constituted in their time and place. Still, I will finish up by making one general critical comment. Although "science" and "sexuality" are thoroughly analyzed and contextualized, unfortunately "morality" remains a container concept throughout all of the contributions. Nonetheless, this volume is a must for those who want to know why sexually transmitted diseases are profitable in Indonesia, why Tibetan women posted their menstrual cycles on communal bulletin boards, what "Number 2 " and "Number 3" stand for in Indian red light districts, what economic bisexuality entails, and why the gay/straight binary cannot adequately describe sexual practices in India.

Open Access This article is distributed under the terms of the Creative Commons Attribution Noncommercial License which permits any noncommercial use, distribution, and reproduction in any medium, provided the original author(s) and source are credited.

\section{References}

Carleton, G. (2005). Sexual revolution in Bolshevik Russia. Pittsburgh, PA: University of Pittsburgh Press.

Healy, D. (2001). Homosexual desire in revolutionary Russia: The regulation of sexual and gender dissent. Chicago: University of Chicago Press. 